LENTERA: JURNAL ILMU DAKWAH DAN KOMUNIKASI

Vol. V, No. 1, Juni 2021

doi: https:// doi.org/10.21093/lentera

https://journal.iain- samarinda.ac.id/index.php/lentera/index

P-ISSN: 2549-7391, E-ISSN: 2549-578X

\begin{tabular}{|l|l|l|}
\hline Received: 12-03-2021 & Accepted: 29-06-2021 & Published: 30-06-2021 \\
\hline
\end{tabular}

\title{
Commodification via the New Media: Content, Audience, and Labour in GoJek's GoFood service
}

\author{
Kun Muhammad Adi \\ Universitas Brawijaya \\ kunmuhammad@student.ub.ac.id \\ Anang Sujoko \\ Universitas Brawijaya \\ anangsujoko@ub.ac.id \\ Antoni \\ Universitas Brawijaya \\ ant_kom@ub.ac.id
}

\begin{abstract}
The existence of new media makes humans have control over the media they consume only through a smartphone on their hands. GoJek contributes new dynamics because the use of new media in the form of an application has changed most of the life patterns of media behavior. In the context of new media, media behavior is inseparable from the concept of political economy communication. This research uses a qualitative approach by extracting information from users, merchants, and drivers on GoFood service features taken by purposive sampling. The collected data from the result of observations, interviews, and documentation will be associated and analyzed using the political economy communication concept of Vincent Mosco, especially the commodification. Researchers found that the aspects of the commodification of content, commodification of audience, and commodification of labor of GoFood service features resulted in changes in society in adapting internet technology which also affected the welfare of the Indonesian economy.
\end{abstract}

Keywords: GoFood, commodification, political economy of communication, and new media

Lentera: Jurnal Ilmu Dakwah dan Komunikasi

Vol. V, No. 1, Juni 2021

P-ISSN: 2549-7391, E-ISSN: 2549-578X

https://journal.iain-samarinda.ac.id/index.php/lentera/index 


\begin{abstract}
Abstrak
Kehadiran media baru membuat manusia memiliki kendali atas media yang mereka konsumsi hanya melalui smartphone di tangannya. Gojek memberikan dinamika baru karena penggunaan media baru berupa aplikasi telah mengubah sebagian besar pola hidup perilaku media. Dalam konteks media baru, perilaku media tidak terlepas dari konsep komunikasi ekonomi politik. Penelitian ini menggunakan pendekatan kualitatif dengan mengolah informasi dari pengguna, merchant dan pengemudi tentang fitur layanan GoFood yang diambil secara purposive sampling. Data yang terkumpul dari hasil observasi, wawancara, dan dokumentasi dikaitkan dan dianalisis menggunakan konsep komunikasi ekonomi politik Vincent Mosco, khususnya aspek komodifikasi. Temuan penelitian ini menunjukan aspek komodifikasi konten, komodifikasi khalayak, dan komodifikasi tenaga kerja fitur layanan GoFood mengakibatkan perubahan masyarakat dalam mengadaptasi dan memanfaatkan teknologi internet pada media baru yang turut mempengaruhi kesejahteraan perekonomian Indonesia.
\end{abstract}

Kata Kunci: Go-Food, ekonomi politik komunikasi, komodifikasi ekonomi dan media baru

\title{
A. INTRODUCTION
}

The increasing role of new media as the infrastructure upon which communication and information sharing paved the way for the development of novel social norms and settings in society (Leah A. Lievrouw \& Sonia Livingstone, 2006). The existence of internet technology as the backbone of new media is an integral part of current media use among people. Almost everyone has access to the internet, whether to access online news portals, social media, or other online applications. Society today needs something instant and practical to make their life easier. It is in this context that online or mobile applications are developed to help people to overcome problems that mostly need instant solutions (Henry Brown Nathalia \& Irwansyah, 2018).

Lentera: Jurnal Ilmu Dakwah dan Komunikasi

Vol. V, No. 1, Juni 2021

P-ISSN: 2549-7391, E-ISSN: 2549-578X

https://journal.iain-samarinda.ac.id/index.php/lentera/index 
The existence of new media as a chain in process of information sharing is very important to the social life of people in society as information is crucial for economic activities such as manufacture, agriculture, mining or extraction of natural resources, management, logistics, marketing, and others. The function of information sharing can be implemented in many settings including public service. One example regarding the implementation of internet technology in the public service sector in Indonesia is GoJek, an online-based service company that provides a range of services ranging from transportation, delivery, and finance.

GoJek has one department focusing on an online-based food delivery service named GoFood. This service is highly popular among Indonesians. This application is known for its' easy access to pricing, location of restaurants, price discounts, and even recommendations of foods and beverages. GoFood provides platforms for potential customers, drivers, and restaurants to make transactions easily. This application can be classified as new media because it is unique since most of its' products and workers are partners (merchant and drivers). Dennis McQuail describes that new media utilize a kind of communication technology that has been digitalized in which users utilize it widely as their communication tools (McQuail, 2010a). In this regard, the communication process is practiced by users, restaurant managers, and drivers through messaging services integrated into the application.

The explanation above describes the actions taken by GoJek to adapt to today's technological developments. The ability to take an action must be done by communicating with fellow individuals or groups in the field of science. In these conditions, tacit knowledge plays an important role in building the mindset of an individual in a group when faced with a phenomenon or problem. The rapid

Lentera: Jurnal Ilmu Dakwah dan Komunikasi

Vol. V, No. 1, Juni 2021

P-ISSN: 2549-7391, E-ISSN: 2549-578X

https://journal.iain-samarinda.ac.id/index.php/lentera/index 
development of internet technology requires sensitivity and innovation in action to think and make effective decisions (Adhikarya, 2008).

Recently, the result of the development of information technology can be used via a smartphone device. Equipped with an internet connection, the smartphone is capable of bringing specific information that people need. The GoJek application, especially the GoFood service provides not only information about products and services but also provides ways for the emergence of new patterns of media consumption. The utilization of new media allows users to explore new experiences in the context of entertainment thus allows them to experience more representational personal satisfaction. All in all, this leads to the implementation of a distinct mode of political economy to the functions of communication within the new media environment.

One concept that can explain the implementation of political economy into the field of communication is the concept of commodification. Commodification refers to a process in which the value of utility turns to exchange value. It means that the functional value of goods/services is getting synonymous with its' mere economical values (Mosco, 2009). In this regard, information shared through the process of communication can be turned into a commodity to be sold by media corporations.

In many media like television, goods to be exchanged are not limited to physical goods as explained by Marx. Instead, it is more likely that those media companies sell ideas that are produced by media workers and are exhibited on television (McQuail, 2010a). The media attract people to watch and consume information thus allowing them to transform the process into a commodity to be sold to potential advertisers. Advertisers, on the other hand, can collect

Lentera: Jurnal Ilmu Dakwah dan Komunikasi

Vol. V, No. 1, Juni 2021

P-ISSN: 2549-7391, E-ISSN: 2549-578X

https://journal.iain-samarinda.ac.id/index.php/lentera/index 
information about the media audiences utilizing technology that is capable of matching potential sellers and buyers optimally (Couldry \& Turow, 2014). The more messages the advertisers can spread effectively to distinct potential customers, the easier it is for them to market their products and services.

Therefore, media can always generate profits from advertisements inserted between their programs. According to Vincent Mosco, there are three types of commodification; commodification of content, the commodification of audience, and the commodification of workers. As the main aspect of media, content is made according to data that reflects the interest of the audience or the kind of information the audience wants. The commodification of audience, on the other hand, the audience is a commodity to the media of which the media could offer potential advertisers limited information about them. Lastly, the media is constantly trying to maximize the competency of their workers by creating a system in which workers feel content about doing their work even though the compensation they get can be regarded as unfair (Mosco, 2009).

GoJek has changed people's behavior from using the conventional motorbike (ojek) transportation service to one that is online based and accessible through the application on a smartphone. Ojek drivers that once have to wait for potential customers in pools (pangkalan ojek), now do not have to wait again since customers can order their service right from their smartphones. The emergence of GoJek thus proves that the utilization of new media can be implemented in many aspects such as the transportation sector. The term new media depicts the growth of media and communication technology in the late '80s. Recent changes in the area of new media, however, are not limited to the field of

Lentera: Jurnal Ilmu Dakwah dan Komunikasi

Vol. V, No. 1, Juni 2021

P-ISSN: 2549-7391, E-ISSN: 2549-578X

https://journal.iain-samarinda.ac.id/index.php/lentera/index 
technology since they also affect people socially, economically, and culturally (Lister et al., 2009).

The characteristics of the media environment from interactivity, mobility, to on-demand functionality, to increased capacity for user-generated content, all serve to increase the extent to which audiences have control over interactions with media (Napoli, 2012). The ever-growing media environment allows for increased content options to be provided across various distribution platforms while, within these many distribution platforms, the capacity to provide more options continues to expand dramatically. For media companies, leveraging technology resources enables media companies to distribute content across multiple platforms with enhanced sound and picture quality in a high-speed broadband environment (Albarran, 2010).

Digital technology has become an inseparable part of people's life. Companies take this opportunity to reach potential consumers through personal information collected through commodification by the media. Equipped with such information, companies can tailor advertisements that suit the characteristics of their potential clients (Aguirre et al., 2016). In the area of new media, the audience or user holds the same position as those of the conventional media. Unconsciously users give media companies new factors of production such as limited personal data that can be sold to advertisement companies. In this research, such data is located in the hands of merchants. With this kind of data, merchants can make targeted marketing of products so detailed it can suit the personal characteristics and needs of people considered potential customers.

Lentera: Jurnal Ilmu Dakwah dan Komunikasi

Vol. V, No. 1, Juni 2021

P-ISSN: 2549-7391, E-ISSN: 2549-578X

https://journal.iain-samarinda.ac.id/index.php/lentera/index 


\section{B. RESEARCH METHOD}

This research utilizes a qualitative approach by extracting information from users, merchants, and drivers on GoFood service features taken by purposive sampling. The collected data will be analyzed using the concept of political economy communication by Vincent Mosco, especially commodification. Researchers, then describe the aspects of the commodification of content, commodification of audience, and commodification of labor of GoFood service features. We also show how such commodification resulted in changes in society in adapting internet technology which also affected the welfare of the Indonesian economy.

\section{RESULTS AND DISCUSSIONS}

1. The commodification of Contents in GoFood service

The commodification of content relates to the contents of a media product that is deemed saleable in the market. Specifically, the process of commodification of communication involves message transformations, from bits of data to meaningful systems of thought to saleable products ready to be marketed (Mosco, 2009). The commodification of content of media needs to be constantly monitored and measured so that products generated can always suit the demand of the market.

Lentera: Jurnal Ilmu Dakwah dan Komunikasi

Vol. V, No. 1, Juni 2021

P-ISSN: 2549-7391, E-ISSN: 2549-578X

https://journal.iain-samarinda.ac.id/index.php/lentera/index 


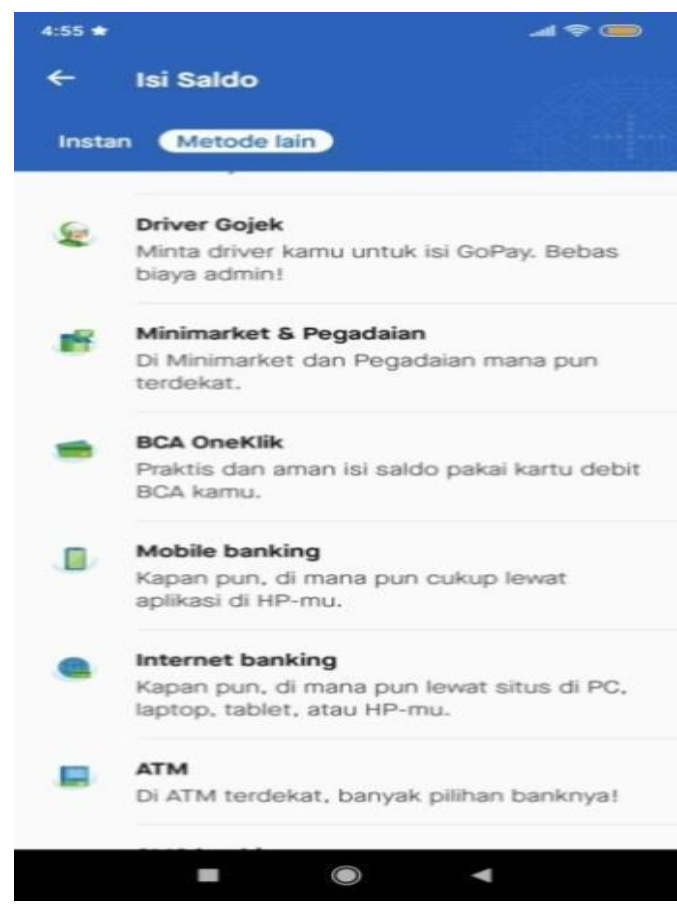

Picture 1. Gopay Screenshot of credit top-up in GoPay system

We see in the case of GoJek that the role of users is quite vital since they are provided with more opportunities to be more active and to have more control in utilizing available services within the GoJek platform. Regarding this, users, for example, can order just any foods and/or beverages they want just by clicking a button on the screen of their smartphone. Moreover, users can also view detailed information about the foods and beverages such as other users' reviews and recommendations, nearest restaurants, and payment options (GoJek has a native digital payment system called GoPay).

Apart from many benefits offered by GoJek, it also offers its' customers some more benefits had they opt to use GoPay as their preferred payment system. Customers, for instance, can top up the credits of their GoPay wallet anytime through Bank's ATM, mobile banking, GoJek's drivers, and through popular retail

Lentera: Jurnal Ilmu Dakwah dan Komunikasi

Vol. V, No. 1, Juni 2021

P-ISSN: 2549-7391, E-ISSN: 2549-578X

https://journal.iain-samarinda.ac.id/index.php/lentera/index 
chains such as Alfamart and Indomaret. As a native payment system in GoJek's environment, GoPay is designed to facilitate easier transactions among users, drivers, and merchants. Easy operation of GoPay is also an added value that can attract GoJek users to use the payment method. In short, the GoPay method of payment has changed people's behavior regarding the use of cash for transactions since it attracts more and more people to do cashless transactions.

2. The commodification of Audience in GoFood service

GoFood application within the GoJek environment makes it more convenient for users to fulfill their need for foods and beverages. Users can order food from their smartphone and drivers would bring the order right to users' doors. The whole process is also simple. GPS technology is used to determine the nearest drivers from merchants thus enabling the most efficient scenario for the users. On the commodification of the audience, information provided by users to the applications to get services is utilized by the application as a commodity to be exchanged with merchants. Merchants, thus, could tailor the most effective marketing strategy out of such information/data.

We can safely assume that GoJek applications are constantly mapping out users' GPS locations when users access the application. Therefore, information regarding the location of the users is dynamic since users tend not to stay in only one or a few places. In other words, the application can also have information about the pattern of users' mobility. All of this information, therefore, can be commodified.

Lentera: Jurnal Ilmu Dakwah dan Komunikasi

Vol. V, No. 1, Juni 2021

P-ISSN: 2549-7391, E-ISSN: 2549-578X

https://journal.iain-samarinda.ac.id/index.php/lentera/index 


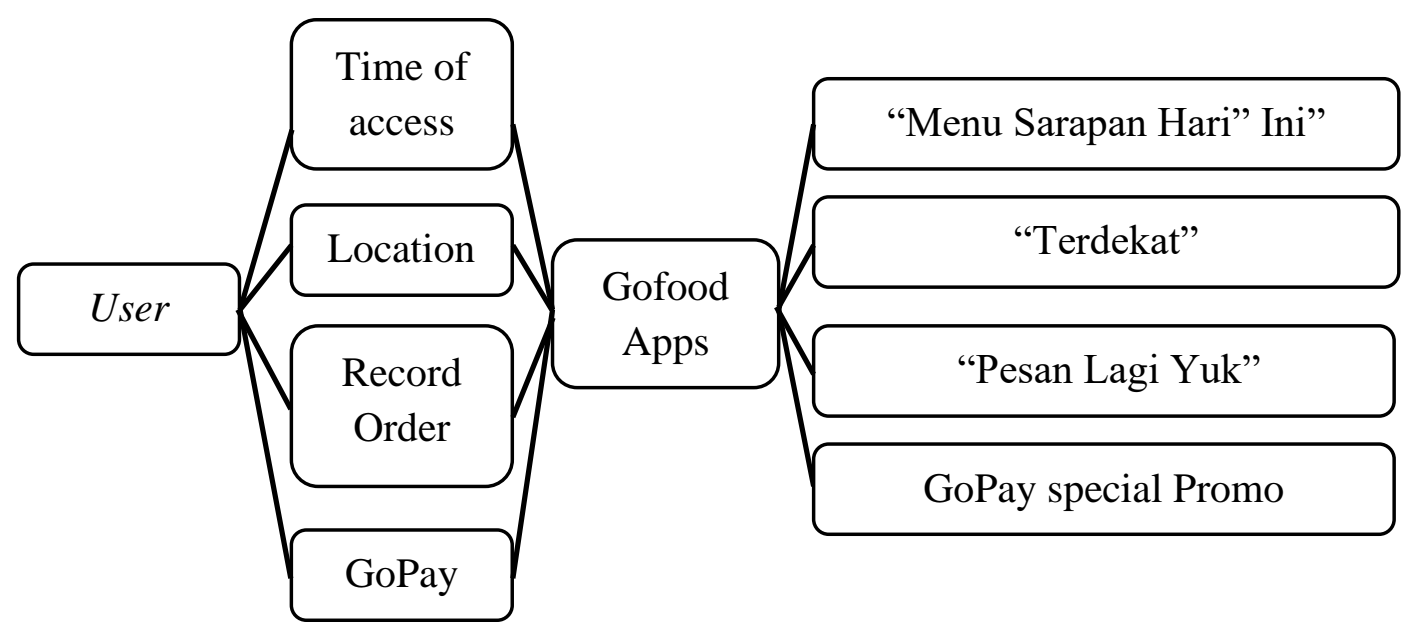

Chart 1. GoFood's utilization of information about users' behavior

Like in other new media, users of the GoJek application provide information that can be converted into exchangeable data to be offered to merchants. The crucial information of users such as time, location, and other patterns of online behavior is deemed very important by merchants that rely heavily on such data to survive the competition. In the case of GoJek, such data could be provided to merchants within the GoJek environment. Below is a chart that shows how information from users are deemed important by merchants (chart 2)

Lentera: Jurnal Ilmu Dakwah dan Komunikasi

Vol. V, No. 1, Juni 2021

P-ISSN: 2549-7391, E-ISSN: 2549-578X

https://journal.iain-samarinda.ac.id/index.php/lentera/index 


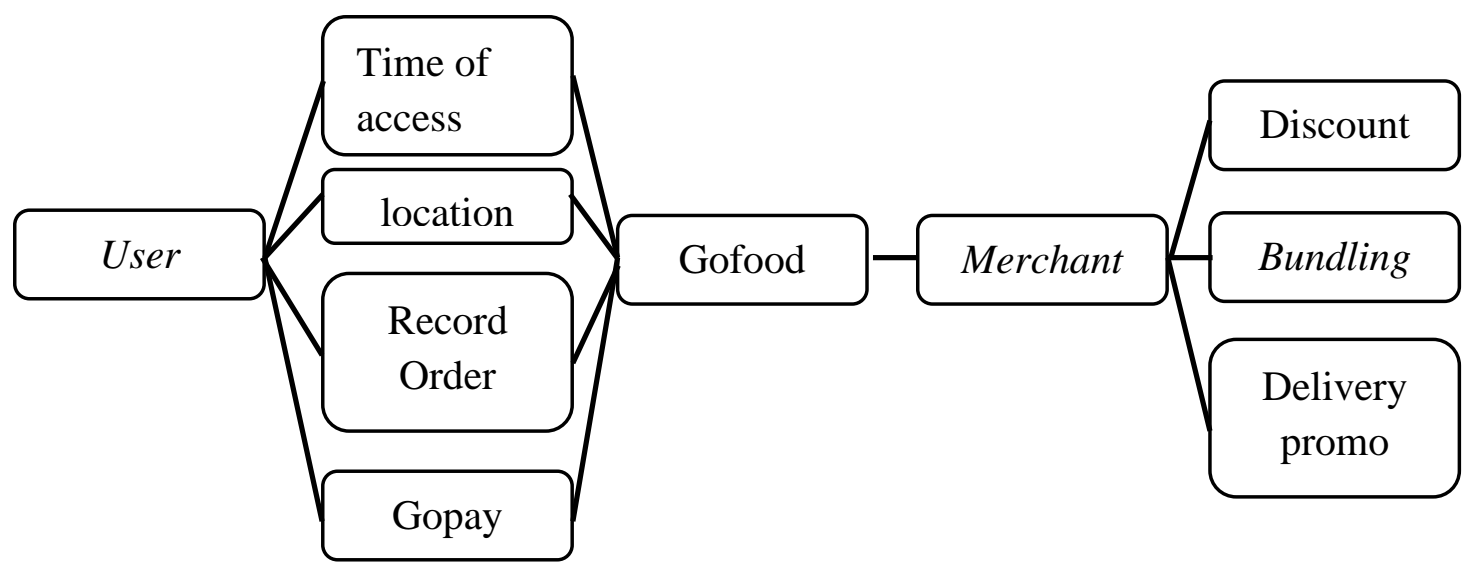

Chart 2. GoFood's utilization of information about users' behavior

Users not only add the intensity of access to the GoJek application in general, but they also provide GoJek with important information regarding their patterns of online behavior that can further be commodified by GoJek.

3. The commodification of Labor in GoFood service

Drivers are the main component that fuels activities in GoJek such as in GoJek transportation service and GoFood delivery service. Drivers in GoJek are called Mitra or partners. Drivers are GoJek's most valuable asset since the core of GoJek's business is run by drivers. A driver in GoJek is responsible for handling orders from the client. The process goes as follows: a client orders a service via the GoJek application on a smartphone, the GoJek application then processes the order to the service provider then offers potential drivers to take the order and deliver it to users who ordered it. After all the process is done, users may give the driver a review of his/her service. This review is crucial in determining the potential income of a driver.

Regarding the working system of GoJek's drivers, new media play an important role as a provider of communication tools equipped with digital

Lentera: Jurnal Ilmu Dakwah dan Komunikasi

Vol. V, No. 1, Juni 2021

P-ISSN: 2549-7391, E-ISSN: 2549-578X

https://journal.iain-samarinda.ac.id/index.php/lentera/index 
features that connect drivers with users. On this, McQuail explains that new media refer mostly to the technology of communication that has undergone digitalization thus are used widely as tools for communication (McQuail, 2010b). In the GoJek platform, this communication involving driver and user happens in a democratic manner in which a driver has an option whether on not to accept an order from the user.

In the context of the commodification of labor, the overall process involved in completing a transaction in the GoJek application is crucial to the drivers. Input from users regarding drivers' performance in completing orders in the form of the performance review is crucial in determining the potential earnings of drivers. We assume that the whole process of rating the driver's performance can lead to inconsistency since users rely heavily on his/her personal subjective experience in giving a performance rating to a driver.

4. GoFood service contributions to the overall economy of Indonesia

Activities within the GoJek's environment, especially within the GoFood service, are related closely to the concept of political economy because it refers to activities involving production, distribution, and consumption. In this regard, political economy is a discipline that studies social relations, especially about the power that shapes productions, distributions, and consumptions of resources including communicational resources (Mosco, 2009).

Production that is applied by GoJek like producing a platform as a gathering point of crucial information related to culinary goods. In addition to being a platform, the GoFood application also gives added value to food and beverage products as they become commodifiable information saleable to

Lentera: Jurnal Ilmu Dakwah dan Komunikasi

Vol. V, No. 1, Juni 2021

P-ISSN: 2549-7391, E-ISSN: 2549-578X

https://journal.iain-samarinda.ac.id/index.php/lentera/index 
merchants. In the GoFood environment, the consumption side is resided mostly by merchants and users in the sense that merchants buy a slot or a place on the GoFood application to showcase their products from which users can make an order.

Users, on the other hand, are end consumers that buy products offered by merchants on the GoFood application. Every transaction made via the GoFood application will be forwarded to drivers whose job is to deliver orders and complete the transaction. In this regard, drivers are practically the main drivetrain that moves the distribution process in GoFood.
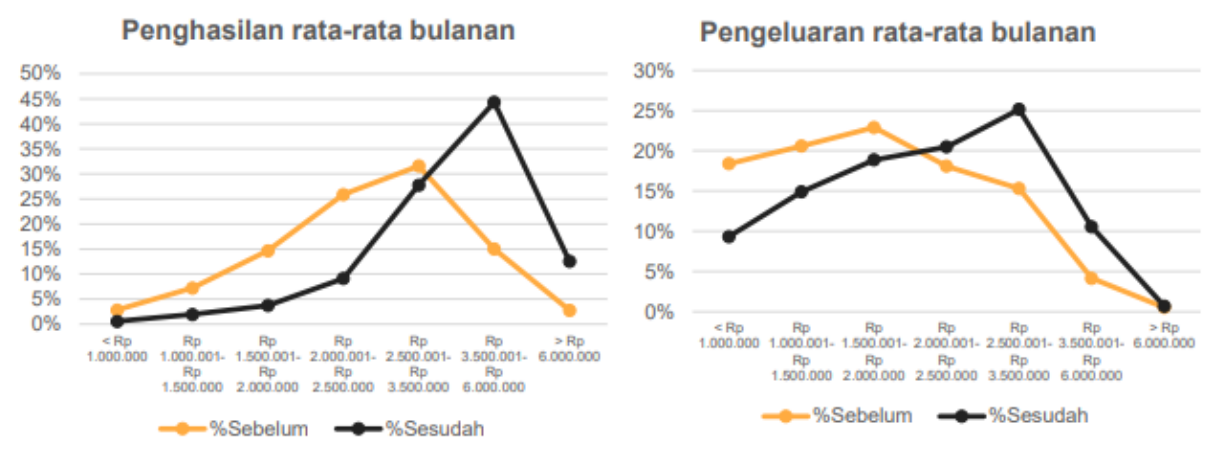

Chart 3. Drivers' average monthly earnings (Lembaga Demografi FEB Universitas Indonesia, 2019)

Beside drivers, merchants which come from small and medium enterprise groups also benefit from GoJek since they now have access to sophisticated internet technology to power their business. GoFood service allows those SME's (Usama Mikro, Kecil, dan Menengah - UMKM) to run their business online. Data from Lembaga Demografi in the faculty of economy and business at the University

Lentera: Jurnal Ilmu Dakwah dan Komunikasi

Vol. V, No. 1, Juni 2021

P-ISSN: 2549-7391, E-ISSN: 2549-578X

https://journal.iain-samarinda.ac.id/index.php/lentera/index 
of Indonesia reveal that the motivation of most SME entrepreneurs to join GoFood is to adopt the development of technology to help to grow their business.
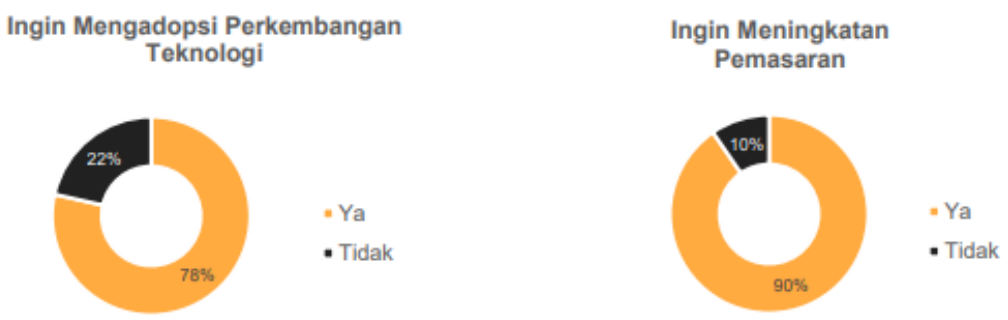

Chart 4. SMEs' motives of joining GoFood (Lembaga Demografi FEB Universitas Indonesia, 2019)

According to the abovementioned picture, we can see that most respondents in many major cities in Indonesia had not yet integrated internet technology into their business before joining GoFood as partners. Moreover, the GoFood application is capable of increasing its earnings through features available within the application. This evidence can be found in a survey conducted by Lembaga Demografi of the Faculty of Economy and Business in the University of Indonesia regarding the earnings of SMEs that joined GoFood as partners.

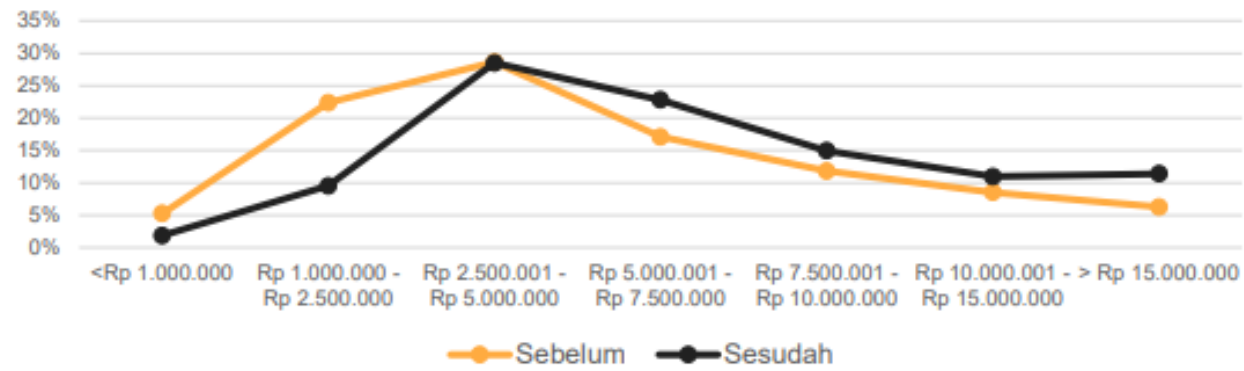

Chart 5. SMEs' turnover per week in 2018(Lembaga Demografi FEB Universitas Indonesia, 2019)

Lentera: Jurnal Ilmu Dakwah dan Komunikasi

Vol. V, No. 1, Juni 2021

P-ISSN: 2549-7391, E-ISSN: 2549-578X

https://journal.iain-samarinda.ac.id/index.php/lentera/index 
Another aspect that has to adapt in this era of digitalization is the payment system. In this regard, one of the most important things in the GoJek environment is the emergence of GoPay, a cashless system of payment native to GoJek. In the Indonesian context, GoPay system has been proven to be the most used system of cashless payment system. (See picture 4).

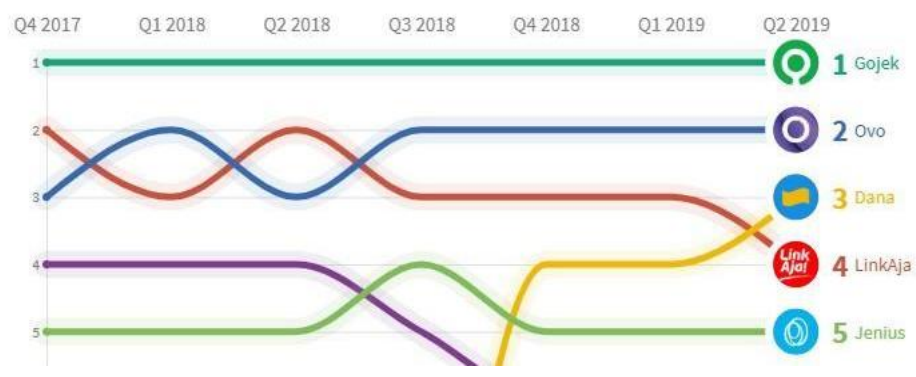

Chart 6. Digital wallet users in Indonesia in 2020 (Jayani, 2020)

In its' development, human activities can not be separated from technology. The emergence of internet technology, in principle, gives people many benefits that make life much easier. At the end of the day, such benefits will be taken for granted. The concept of political economy implemented in GoJek gives us a broad picture of how the emergence of internet technology, directly or indirectly, forces people to adapt.

Lentera: Jurnal Ilmu Dakwah dan Komunikasi

Vol. V, No. 1, Juni 2021

P-ISSN: 2549-7391, E-ISSN: 2549-578X

https://journal.iain-samarinda.ac.id/index.php/lentera/index 


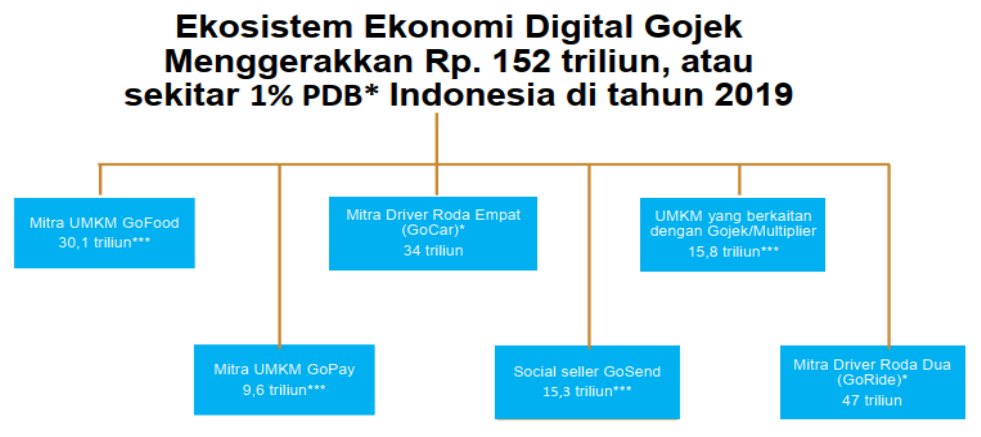

Chart 7. GoJek's contribution to the economy of Indonesia in 2019 (Lembaga Demografi

FEB Universitas Indonesia, 2020)

We can see that how adaptations are being implemented in the GoJek environment is the key factor that places this application ahead of its' competitors (See chart 4). As an aggregate of total economic activities on a large/national scale (macroeconomy), the emergence of the GoFood application contributes significantly to the overall economy of Indonesia.

Several global research bodies such as UXalliance, Usaria, and Somia CX have released their reports of a survey regarding the most user/customer friendly in the world. The research was conducted from April to May 2020. The research that has been named "Delivery Apps in Time of COVID-19: Global Benchmark" revealed that during the time of Covid-19 pandemic, the GoFood application rank number one in the world regarding user experience (UX) and number two regarding customer experience (CX). (See picture 5)

Lentera: Jurnal Ilmu Dakwah dan Komunikasi

Vol. V, No. 1, Juni 2021

P-ISSN: 2549-7391, E-ISSN: 2549-578X

https://journal.iain-samarinda.ac.id/index.php/lentera/index 

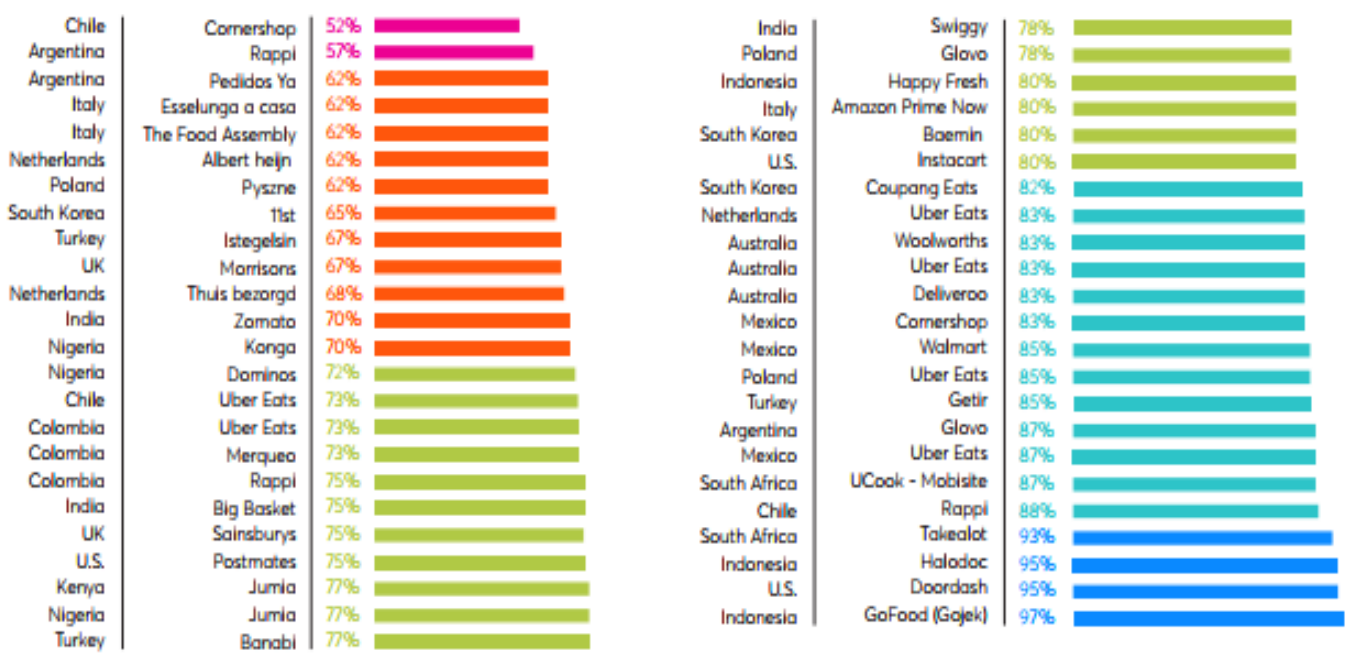

Chart 8. Rankings of applications according to user experiences (Delivery Apps in Time of COVID-19 - Global Benchmark, 2020)

Characteristics of interactivity within the atmosphere of new media also form collaboration among elements or parties that aim at similar goals. The GoJek application, especially the GoFood, provides a platform for many parties such as buyers, food sellers, and ojek drivers to interact through online applications and in the real world. Accumulation of economic activities within the GoJek environment contributes to the overall economy of the country.

\section{CONCLUSIONS}

GoPay method of payment is part of the transaction process in GoJek environment that has been commodified into an exchangeable/saleable product. A range of benefits from using this payment method includes price discount, bundling promo, to free delivery cost. These benefits have become the norm regarding digital transactions to fulfill daily basic grocery, food, and beverages

Lentera: Jurnal Ilmu Dakwah dan Komunikasi

Vol. V, No. 1, Juni 2021

P-ISSN: 2549-7391, E-ISSN: 2549-578X

https://journal.iain-samarinda.ac.id/index.php/lentera/index 
Kun Muhammad Adi et. al.Commodification via the New Media...

needs. GoPay has also formed a set of new habits in society in which people are more likely to use cashless transactions in their daily life.

Users of the GoJek application are consciously giving the application detailed information such as times and locations, order records, and others. This type of data is handled over not as general information regarding clients but as a commodified information data saleable to merchants because this could help them be more precise in their marketing. GoJek also managed to transform the traditional ojek service known as ojek pangkalan into a modern and professional internet-based transportation service. As GoJek also introduced its' system of rewards/incentives to drivers, a new set of work ethics emerged since drivers' earnings are determined by how professional they deliver their services.

Lentera: Jurnal Ilmu Dakwah dan Komunikasi

Vol. V, No. 1, Juni 2021

P-ISSN: 2549-7391, E-ISSN: 2549-578X

https://journal.iain-samarinda.ac.id/index.php/lentera/index 


\section{Bibliography}

Adhikarya, Ronny. "Challenges for Communication and Social Networks in a Flat World: "Tacit" Knowledge Management and Sharing for a K-Based Society." Media Asia 35, no. 4 (January 2008): 259-68. https://doi.org/10.1080/01296612.2008.11771966

Aguirre, E., Roggeveen, A. L., Grewal, D., \& Wetzels, M. (2016). The personalization-privacy paradox: Implications for new media. Journal of Consumer Marketing, 33(2), 98-110. https://doi.org/10.1108/JCM-062015-1458

Albarran, Alan B. The Media Economy. Routledge, 2010. https://doi.org/10.4324/9780203927717

Couldry, N., \& Turow, J. (2014). Advertising, Big Data, and The Clearance of The Public Realm: Marketers' New Approaches to The Content Subsidy. International Journal of Communication, 8, 17.

Henry Brown Nathalia \& Irwansyah. (2018). Aplikasi Transportasi Online GOJEK: Bentuk dari Konstruksu Sosial Teknologi dalam Media Baru. Mediator: Jurnal Komunikasi, 11(2).

Jayani, D. H. (2020, August 19). Persaingan Dompet Digital di Indonesia, Gopay Miliki Pengguna Terbanyak / Databoks. https://databoks.katadata.co.id/datapublish/2020/08/19/persaingandompet-digital-di-indonesia-gopay-miliki-pengguna-terbanyak

Leah A. Lievrouw \& Sonia Livingstone. (2006). Handbook of New Media: Social Shaping and Social Consequences of ICTs, Updated Student Edition. SAGE Publication.

Lembaga Demografi FEB Universitas Indonesia. (2019). Lembaga Demografi FEB UI - Dampak Sosial dan Ekonomi Gojek 2018. Lembaga Demografi FEB Universitas Indonesia. https://ldfebui.org/wpcontent/uploads/2019/03/Lembaga-Demografi-FEB-UI-Dampak-Sosialdan-Ekonomi-GOJEK-2018.pdf

Lembaga Demografi FEB Universitas Indonesia. (2020). Dampak Ekonomi Gojek 2019 (p. 16). Lembaga Demografi FEB Universitas Indonesia.

Lentera: Jurnal Ilmu Dakwah dan Komunikasi

Vol. V, No. 1, Juni 2021

P-ISSN: 2549-7391, E-ISSN: 2549-578X

https://journal.iain-samarinda.ac.id/index.php/lentera/index 
Kun Muhammad Adi et. al.Commodification via the New Media...

https://drive.google.com/file/d/1CHgE_PGHUjeslovrMliMLK6fWLwjm0F/view

Lister, M., Dovey, J., Giddings, S., Grant, I., \& Kelly, K. (2009). New Media: A Critical Introduction (2nd ed). Routledge.

McQuail, D. (2010a). Mcquail's Mass Communication Theory (6th ed). Sage Publications.

McQuail, D. (2010b). Mcquail's mass communication theory (6th ed). Sage Publications.

Mosco, V. (2009). The Political Economy of Communication. SAGE Publications Ltd. https://doi.org/10.4135/9781446279946

Murillo, M. I., Rocha, D. T., Escobar, Pamela, \& Avellaneda, V. (Eds.). (2020). Delivery Apps in Time of COVID-19-Global Benchmark (p. 227). UXAlliance. https://usaria.mx/globalresearch/DeliveryAppsintimeofCOVID19_Research_Usaria_UXAlliance_15 0720.pdf

Napoli, Philip M. "Audience Evolution and the Future of Audience Research." International Journal on Media Management 14, no. 2 (April 2012): 79-97. https://doi.org/10.1080/14241277.2012.675753.

Lentera: Jurnal Ilmu Dakwah dan Komunikasi

Vol. V, No. 1, Juni 2021

P-ISSN: 2549-7391, E-ISSN: 2549-578X

https://journal.iain-samarinda.ac.id/index.php/lentera/index 